\title{
Gender Gap - nierówności ekonomiczne w krajach europejskich ze względu na płeć
}

\section{Wstęp}

W przestrzeni gospodarczej można spotkać się z wieloma rodzajami nierówności społecznych. Dotyczą one różnych aspektów, np.: dochodów i poziomu konsumpcji, dostępu do informacji, pracy, możliwości korzystania z dóbr kultury, warunków rozwijania i spożytkowania osobistych uzdolnień, możliwości udziału w życiu publicznym, osiaganiu prestiżu społecznego. Nierówności występują zarówno między krajami, wewnątrz państw, między grupami społecznymi, jak i między poszczególnymi członkami społeczności ludzkiej.

Jednym z rodzajów nierówności występującym we współczesnym świecie jest nierówność ze względu na płeć. Zasadnicza przyczyna tej nierówności tkwi w charakterze struktur instytucji społecznych oraz w systemach wartości i subiektywnych poglądów, które tworzą i pogłębiają tę różnicę. Dyskryminacja społeczna kobiet obejmuje różne sfery życia, w tym przede wszystkim sferę ekonomiczną oraz polityczną.

\section{Cel i metoda badań}

Przedmiotem niniejszego opracowania jest problematyka nierówności według płci rozpatrywana w krajach europejskich w latach 2012-2013, a celem opracowania analiza i ocena zróżnicowania państw europejskich z punktu widzenia równych szans kobiet i mężczyzn w pięciu kluczowych obszarach: gospodarka, edukacja, zdrowie, polityka oraz rolnictwo. Przeprowadzone badania skupiają się na analizach z wykorzystaniem wskaźników gender stosowanych 
w statystyce międzynarodowej: Gender Pay Gap oraz Global Gender Gap Index. Do realizacji celu badawczego wykorzystano literaturę przedmiotu oraz wtórne dane statystyki Eurostat, a także dane World Economic Forum. W artykule posłużono się metodą analizy porównawczej. Wyniki badań zestawiono w formie wykresów.

\section{Pojęcie nierówności, dyskryminacji i równouprawnienia}

Przyczynami zainteresowania w naukach społecznych, w tym w ekonomii, tematyką nierówności społecznych są zarówno względy ideologiczne, jak i próba uchwycenia przemian struktury społecznej. W literaturze poświęconej problematyce nierówności można znaleźć wiele różnych definicji tego pojęcia. Ich niejednorodny charakter wynika przede wszystkim z dynamiki przemian nierówności w różnych sferach życia. Jedna z definicji nierówności społecznych mówi, że jest ona ,środkiem, dzięki któremu społeczeństwo zapewnia sumienną obsadę najważniejszych pozycji przez najbardziej kwalifikowane osoby. Stąd każde społeczeństwo, niezależnie od tego, czy jest proste czy skomplikowane, musi różnicować ludzi według prestiżu i szacunku, i musi zawierać pewien stopień zinstytucjonalizowanej nierówności" [Kokociński 2009]. Nierówności społeczne są zatem nierównością struktury społecznej, opartej na nierównym podziale dochodów i prestiżu społecznego (nierówny podział dóbr materialnych, a także niematerialnych w społeczeństwie).

Z kolei Zachorowska-Mazurkiewicz definiuje nierówności jako „sytuację, w której poszczególne jednostki nie mogą w pełni korzystać z przywilejów dostępnych innym lub także, że są wprost inaczej (gorzej) traktowane tylko ze względu na przynależność do pewnej grupy bądź kategorii społecznej” [Zachorowska-Mazurkiewicz 2011]. Według Sztompki, „nierówności społeczne dotyczą nie cech indywidualnych, lecz innego rodzaju cech, tych cech pośrednich, które upodabniają do siebie pewne tylko zbiorowości - grupy społeczne, albo pewne tylko lokalizacje w społecznej strukturze - pozycje społeczne (statusy). Inaczej, nierówności społeczne dotyczą sytuacji, gdy ludzie są nierówni sobie nie $\mathrm{z}$ racji jakichkolwiek cech cielesnych czy psychicznych, lecz z powodu ich przynależności do różnych grup albo zajmowania różnych pozycji społecznych" [Sztompka 2002]. Z kolei Goodman określa nierówności społeczne jako „różnice między jednostkami wynikające z nierównego rozdzielania dóbr przez społeczeństwo, ale także z tego, że pewne osoby pracują ciężej od innych, lub wybrały zawód czy karierę zapewniającą więcej władzy niż inne" [Goodman 1988].

Obok pojęcia nierówności w literaturze przedmiotu funkcjonuje termin dyskryminacja. Definicja dyskryminacji odnosi się do łacińskiego słowa discrimina- 
tio oznaczającego rozróżnienie i nierówne traktowanie, wybiórczą ocenę. Turner i Musick [1985] określają dyskryminację jako ,proces, w toku którego członkowie jednej, rozpoznawalnej populacji działają w celu zamknięcia dostępu innej rozpoznawalnej populacji do cenionych dóbr, takich jak pieniądze, władza, prestiż, prawa obywatelskie, miejsca pracy oraz inne cenione dobra".

$Z$ dyskryminacją ze względu na płeć mamy do czynienia wtedy, gdy dana osoba jest gorzej traktowana, ponieważ przynależy do określonej płci (dyskryminacja bezpośrednia), jak również i wtedy, gdy płeć nie jest oficjalnym kryterium nierówności, np. wówczas, kiedy pozornie neutralne prawo, polityka czy praktyka dają negatywny efekt dla osób należących do określonej płci (dyskryminacja pośrednia).

Równouprawnienie oznacza równe prawa kobiet i mężczyzn, równe możliwości samorealizacji w sferze prywatnej i publicznej. Jest to wolność w podejmowaniu decyzji bez ograniczeń narzucanych przez role płci. Równość jest wtedy, gdy obu płciom przypisuje się równą społeczną wartość, prawa i obowiązki, równy dostęp do zasobów i dóbr. Warto zaznaczyć, że chodzi tu o równe prawa do realizacji takich samych lub różnych potrzeb ludzi niezależnie od płci. Nie znaczy to, że kobiety i mężczyźni mają być lub są identyczni. Uczestnictwo na równych prawach i szanse kobiet oraz mężczyzn w życiu społecznym, ekonomicznym i politycznym są warunkiem osiagnnięcia zrównoważonego rozwoju, pokoju, bezpieczeństwa i jest to konieczne do pełnego poszanowania praw człowieka.

W artykule pojęcie nierówności społecznych jest rozumiane jako nierówny dostęp do cenionych dóbr, takich jak: bogactwo, władza, prestiż, wykształcenie, zdrowie, zawód, a więc podejście wyraźnie korespondujące z definicjami nierówności społecznych według Goodmana i Sztompki.

\section{Pomiar nierówności społecznych według płci}

Na wstępie należy zaznaczyć, iż prowadzone badania dotyczące nierówności płci nie oceniają, czy sytuacja kobiet i mężczyzn jest dobra czy też zła, a jedynie informują o różnicach w sytuacji kobiet i mężczyzn.

Najbardziej znanymi wskaźnikami syntetycznymi mierzącymi równość płci są wskaźniki używane w międzynarodowych badaniach porównawczych. Stanowią one instrumenty badawcze pozwalające na uszeregowanie państw, zbudowanie listy rankingowej oraz wyróżnienie państw, których polityka prowadzi do najbardziej wyrównanej sytuacji kobiet i mężczyzn w różnych obszarach życia społeczno-gospodarczego [Rawłuszko 2007, s. 17-18].

Jednym z takich wskaźników jest luka płacowa (gender pay gap, gender wage gap). Wskaźnik ten przedstawia różnicę w przeciętnych godzinowych wynagro- 
dzeniach brutto kobiet i mężczyzn [Przeciwdziałanie... 2014, s. 5]. Wskaźnik luki płacowej nie uwzględnia wszystkich czynników wpływających na różnicę w poziomach wynagrodzeń kobiet i mężczyzn (np.: wykształcenie, staż, stanowisko, branża). Pokazuje on ogólny wymiar nierówności wynagrodzeń między płciami w skali danego kraju. Luka płacowa nie wyznacza więc różnicy wysokości wynagrodzeń kobiet i mężczyzn znajdujących się w tej samej sytuacji zawodowej (to samo stanowisko, kwalifikacje, staż pracy itd.), lecz pokazuje różnicę w poziomie wynagrodzeń między płciami wynikającą m.in. $z$ tego, że kobiety pracują w gorzej wynagradzanych branżach, częściej w niepełnym wymiarze czasu pracy, rzadziej zajmują wysoko wynagradzane stanowiska kierownicze.

Badania Eurostatu pokazały, że w 2012 roku, godzinowe zarobki brutto kobiet były średnio o 16,4\% niższe od zarobków mężczyzn w Unii Europejskiej (UE-28) i $16 \% \mathrm{w}$ strefie euro (EA-17) ${ }^{1}$. W poszczególnych państwach członkowskich różnica płac kształtowała się od 2,5\% w Słowenii do 30,0\% w Estonii (rys. 1). Sześć krajów UE wykazywało lukę płacową poniżej 10\%. Do grona tych państw należą: Rumunia, Luksemburg, Włochy, Polska, Malta oraz Słowenia. W tych krajach kobiety bardzo rzadko zajmują się pracą w niskopłatnych zawodach wymagających niskich kwalifikacji. Są to też kraje o dość dużym odsetku kobiet biernych zawodowo. Poniżej unijnej średniej znajdują się także: Belgia, Bułgaria, Irlandia, Francja, Łotwa, Litwa, Portugalia, Szwecja i Norwegia. Najwyższe wskaźniki luki płacowej odnotowano w Estonii, Austrii, Belgii, Danii, Czechach oraz Słowacji, co wynika z dużej liczby kobiet pracujących w tych krajach w niepełnym wymiarze czasu pracy.

W 2012 roku różnice w poziomie płac kobiet i mężczyzn w większości krajów były wyższe w sektorze prywatnym niż publicznym. W sektorze publicznym najkorzystniejsza dla kobiet sytuacja była w Belgii, gdzie kobiety zarabiały o 3\% więcej niż mężczyźni oraz na Cyprze, gdzie różnica wynosiła $0,3 \%$ na korzyść mężczyzn. Bardzo dobrze wypadała też Polska - mężczyźni zarabiali o 3,7\% więcej niż kobiety. Największe różnice na korzyść mężczyzn były na Węgrzech - 24,4\% oraz w Czechach - 21,2\%. Inaczej wskaźnik luki płacowej kształtował się w sektorze prywatnym, gdzie we wszystkich krajach mężczyźni zarabiali wyraźnie więcej niż kobiety. Najlepiej wyglądała sytuacja w Słowenii, gdzie różnica między płciami wynosiła $8,9 \%$ oraz w Bułgarii - 12,4\%. W Polsce mężczyźni zarabiali o $16,1 \%$ więcej od kobiet. Najwyższe dysproporcje odnotowana w Portugalii, gdzie różnica wynosiła aż $29,4 \%$ i w Niemczech - 25,7\% [Gender... 2014].

\footnotetext{
${ }^{1}$ Dane dotyczące różnicy w wynagrodzeniach kobiet i mężczyzn są oparte na badaniu struktury zarobków (SES) przeprowadzanym co cztery lata przez Eurostat.
} 


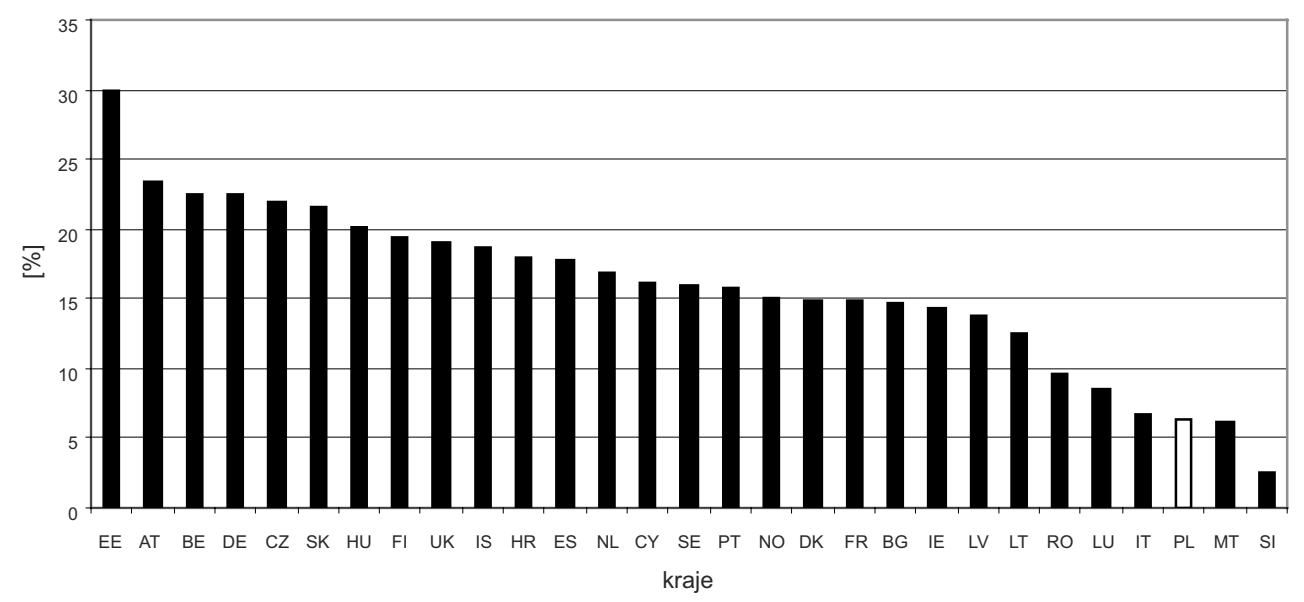

\section{Rysunek 1}

Wskaźnik luki płacowej (Gender Pay Gap) w krajach europejskich w 2012 roku [\%]; EE - Estonia, AT - Austria, BE - Belgia, DE - Niemcy, CZ - Czechy, SK - Słowacja, HU - Węgry, FI - Finlandia, UK - Wielka Brytania, IS - Islandia, HR - Chorwacja, ES - Hiszpania, NL - Holandia, CY - Cypr, SE - Szwecja, PT - Portugalia, NO - Norwegia, DK - Dania, FR - Francja, BG - Bułgaria, IE - Irlandia, LV - Łotwa, LT - Litwa, RO - Rumunia, LU - Luksemburg, IT - Włochy, PL - Polska, MT - Malta, SI - Słowenia

Źródło: Opracowanie własne na podstawie: Gender pay gap statistics, Eurostat, http:// epp.eurostat.ec.europa.eu/statistics_explained/index.php/Gender_pay_gap_statistics (data dostępu: 10.04.2014).

W krajach europejskich sytuacja kobiet i mężczyzn jest zróżnicowana, także ze względu na rodzaj umowy o pracę. W przypadku umów na czas określony znacznie większe różnice między płciami - na korzyść mężczyzn - występowały w Hiszpanii i Portugalii - ponad 25\%. Na Malcie i w Irlandii kobiety zarabiały więcej od mężczyzn przy tego rodzaju umowach [Gender... 2014].

Istotnym elementem, który wpływa na rozwarstwienie dochodów między płciami, jest też wiek. W większości krajów najmniejsze różnice w dochodach między płciami występowały u osób do 25. roku życia, a stosunkowo nieduże - w grupie 25-34 lata. Znacznie większe różnice dochodowe między kobietami i mężczyznami odnotowano wśród osób między 35. a 64. rokiem życia [Gender... 2014].

Kolejnym wskaźnikiem wykorzystywanym do oceny poziomu nierówności społecznych ze względu na płeć jest obliczany przez World Economic Forum wskaźnik nierówności płci - Global Gender Gap Index. Indeks ten analizuje różnice między mężczyznami i kobietami w czterech podstawowych kategoriach: gospodarka, osiągnięcia w edukacji, władza polityczna oraz zdrowie. GGGI bada dystrybucję tych dóbr wśród kobiet i mężczyzn, a nie ich ogólny poziom w kraju. Przez to pokazuje sytuację niezależnie od poziomu rozwoju danego państwa. 
Dla każdej z wyróżnionych kategorii tworzony jest oddzielny subindeks, budowany na podstawie przyjętych zmiennych (tab. 1). Subindeks gospodarka oparty jest o cztery wskaźniki uwzględniające m.in. aktywność zawodowa, wysokość pensji, udział i dostęp do stanowisk wymagających wysokich kwalifikacji. Osiągnięcia w edukacji obejmują dostęp do podstawowej i wyższej edukacji oraz stopę analfabetyzmu. Subindeks zdrowie uwzględnia średnią długość życia oraz relację płci w chwili urodzenia. Ostatni indeks dotyczący równouprawnienia politycznego zbudowany jest o trzy istotne zmienne, które oceniają udział kobiet $\mathrm{w}$ strukturach decyzyjnych. Większość użytych do stworzenia indeksu wskaźników pochodzi z publicznie dostępnych „twardych danych” zebranych przez takie międzynarodowe organizacje, jak Międzynarodowa Organizacja Pracy (ILO), Światowa Organizacja Zdrowia (WHO) czy United Nations Development Programme [Sobczak 2013, s. 72].

Indeks Global Gender Gap oznaczany jest jako liczba pomiędzy 0,00 (przyjęte jako nierówność we wszystkich badanych wskaźnikach) a 1 (całkowita równość w badanych wskaźnikach). Wynik danego kraju informuje, ile nierówności udało się zlikwidować (np. 0,850 oznacza, że udało się zlikwidować $85 \%$ badanych nierówności).

Dane WEF pokazują, że w 2013 roku najwięcej nierówności między płciami (powyżej 80\%) udało się zlikwidować w czterech europejskich krajach: Islandii, Finlandii, Norwegii oraz w Szwecji (rys. 2). Druga grupa krajów z poziomem wskaźnika między 70 a $80 \%$ obejmowała 19 krajów, z czego większość z nich ma wskaźnik poniżej 75\%. Grupę tę zamyka Polska ze wskaźnikiem na pozio-

\section{Tabela 1}

Zmienne wykorzystywane do tworzenia subindeksów wskaźnika Global Gender Gap Index

\begin{tabular}{|l|l|}
\hline Subindeks & \multicolumn{1}{|c|}{ Zmienne } \\
\hline Gospodarka & $\begin{array}{l}\text { poziom zatrudnienia kobiet i mężczyzn, wysokość płac, równość płac } \\
\text { za podobna prace, dostęp do stanowisk wymagających wysokich } \\
\text { kwalifikacji (wyodrębnia się dwie grupy takich stanowisk: legislatorzy, } \\
\text { urzędnicy wysokiej rangi i menedżerowie oraz specjaliści i pracownicy } \\
\text { techniczni) }\end{array}$ \\
\hline $\begin{array}{l}\text { Osiagnięcia w edu- } \\
\text { kacji }\end{array}$ & $\begin{array}{l}\text { stopa analfabetyzmu, dostęp do podstawowej, średniej i wyższej edu- } \\
\text { kacji }\end{array}$ \\
\hline $\begin{array}{l}\text { Zdrowie i długość } \\
\text { życia }\end{array}$ & $\begin{array}{l}\text { urodzenia według płci (stosunek liczby urodzeń kobiet do liczby męż- } \\
\text { czyzn), średnia długość życia }\end{array}$ \\
\hline $\begin{array}{l}\text { Równouprawnienie } \\
\text { polityczne }\end{array}$ & $\begin{array}{l}\text { reprezentacja płci w parlamencie, na stanowiskach } \\
\text { ministerialnych, w najwyższych władzach (stanowisko premiera lub } \\
\text { prezydenta w ostatnich 50 latach) }\end{array}$ \\
\hline
\end{tabular}

Źródło: Opracowanie własne na podstawie: The Global Gender Gap Report 2013, World Economic Forum 2013, s. 13. 


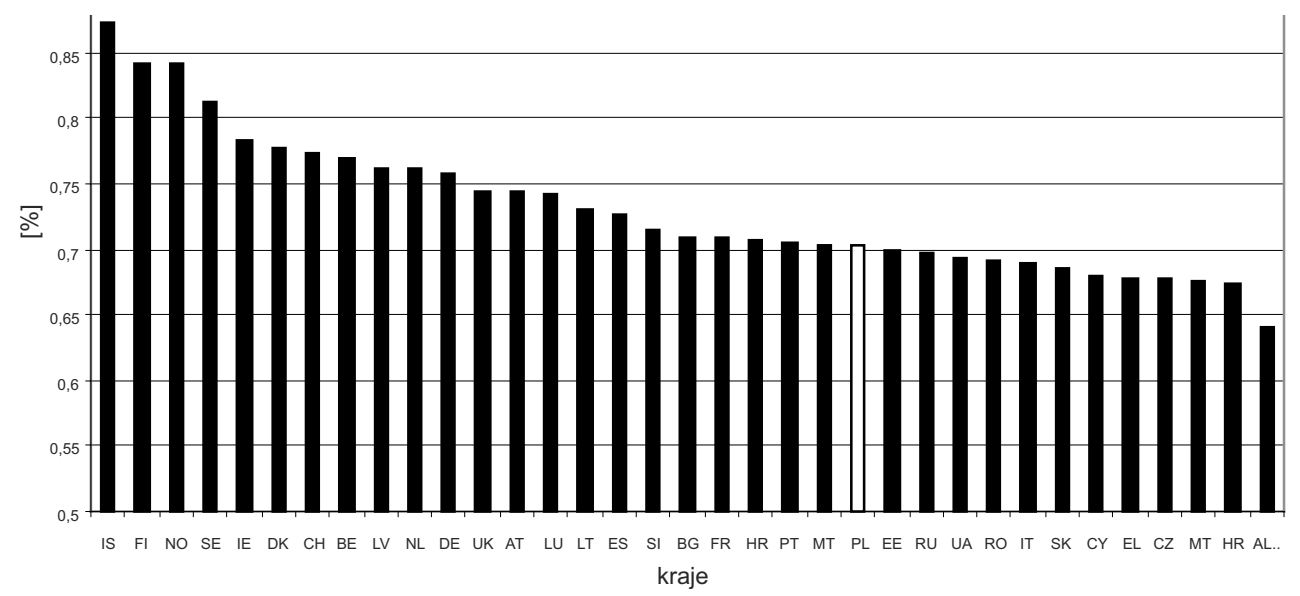

\section{Rysunek 2}

Wskaźnik Global Gender Gap w krajach europejskich w 2013 roku [\%]; objaśnienia jak pod rysunkiem 1

Źródło: Opracowanie własne na podstawie: The Global Gender Gap Report 2013, World Economic Forum 2013, s. 8-11.

mie 0,7031 . Trzecia grupa państw to kraje o największych nierównościach między płciami - wskaźnik poniżej 70\%. Wśród tych krajów należy wymienić m.in. Estonię, Rosję, Ukrainę oraz Włochy. Najniższy indeks Gender Gap odnotowano w Albanii - 0,6412.

W latach 2009-2013 łączny wynik Global Gender Gap dla Europy zmniejszył się o 0,3 p.p. Spadek ten można tłumaczyć przede wszystkim spadkiem subindeksu zdrowie i długość życia, który nie został w pełni zrównoważony przez wzrost innych subindeksów.

Analizując wskaźnik Gender Gap ze względu na wyróżnioną kategorię, można zauważyć większe odchylenia niż w przypadku indeksu ogólnego.

Pierwszy z subindeksów, badający nierówności między płciami w obszarze gospodarki, pokazuje bardzo duże różnice pomiędzy krajami europejskimi - o 41 p.p. (rys. 3). Najwięcej nierówności ekonomicznych między kobietami i mężczyznami udało się zlikwidować w Norwegii - 83\% oraz w Luksemburgu - $81 \%$, natomiast najmniej w Czechach, we Włoszech oraz na Malcie - poniżej $60 \%$. W większości krajów wskaźnik ten oscylował między 70 a $80 \%$. W ogólnej klasyfikacji należy wskazać na Litwę, która jest krajem z najwyższą pozycją w regionie jeśli chodzi o wskaźnik aktywności zawodowej, jak również wskaźnik pracowników technicznych i fachowców. Polska znalazła się na 27. miejscu, z indeksem poniżej średniej europejskiej - z poziomem likwidacji nierówności $65 \%$. 


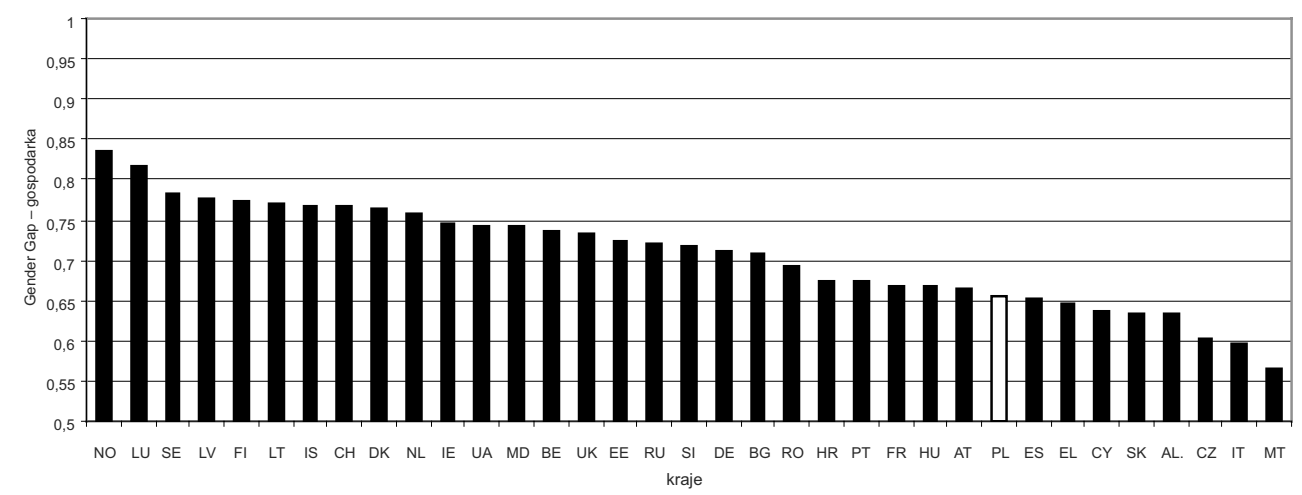

\section{Rysunek 3}

Wskaźnik Gender Gap - gospodarka w 2013 roku [\%]; objaśnienia jak pod rysunkiem 1 Źródło: Opracowanie własne na podstawie: The Global Gender Gap Report 2013, World Economic Forum 2013, s. 12-13.

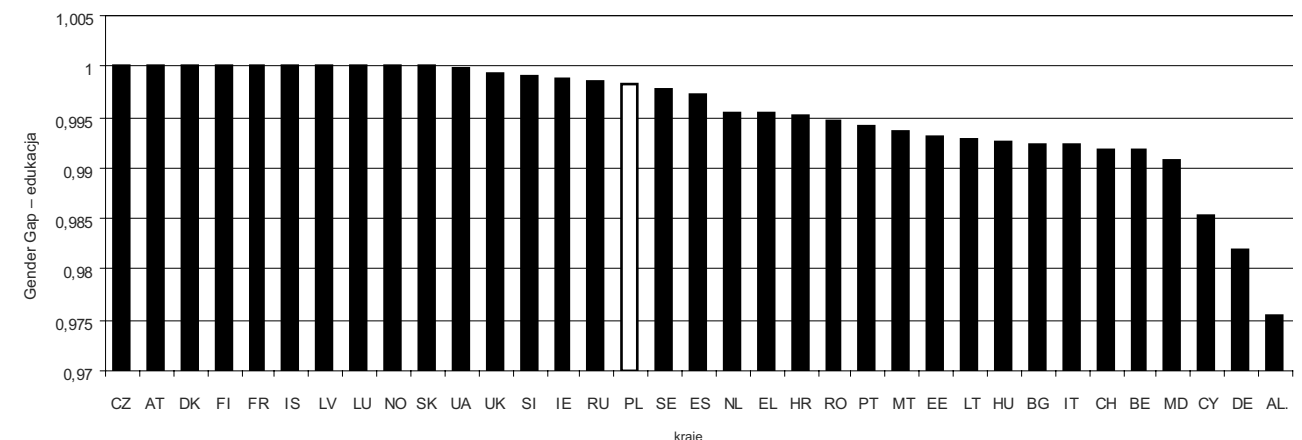

\section{Rysunek 4}

Wskaźnik Gender Gap - edukacja w 2013 roku [\%]; objaśnienia jak pod rysunkiem 1

Źródło: Opracowanie własne na podstawie: The Global Gender Gap Report 2013, World Economic Forum 2013, s. 12-13.

W 2013 roku indeks badający poziom wyrównania nierówności płci w zakresie edukacji oscylował w granicy górnej normy (rys. 4). W 10 państwach europejskich (Finlandii, Norwegii, Danii, Czechach, Austrii, Francji, Islandii, Luksemburgu Słowacji oraz na Łotwie) zlikwidowano 100\% nierówności między kobietami i mężczyznami. W pozostałych państwach wskaźnik ten przybierał równie wysokie wartości od 97\% w Albanii do 99\% w pozostałych państwach. Polska uplasowała się na 16. pozycji z indeksem na poziomie 99\%. Portugalia jest krajem mającym najwyższą pozycję jeśli chodzi o wskaźnik edukacji na poziomie średnim. 


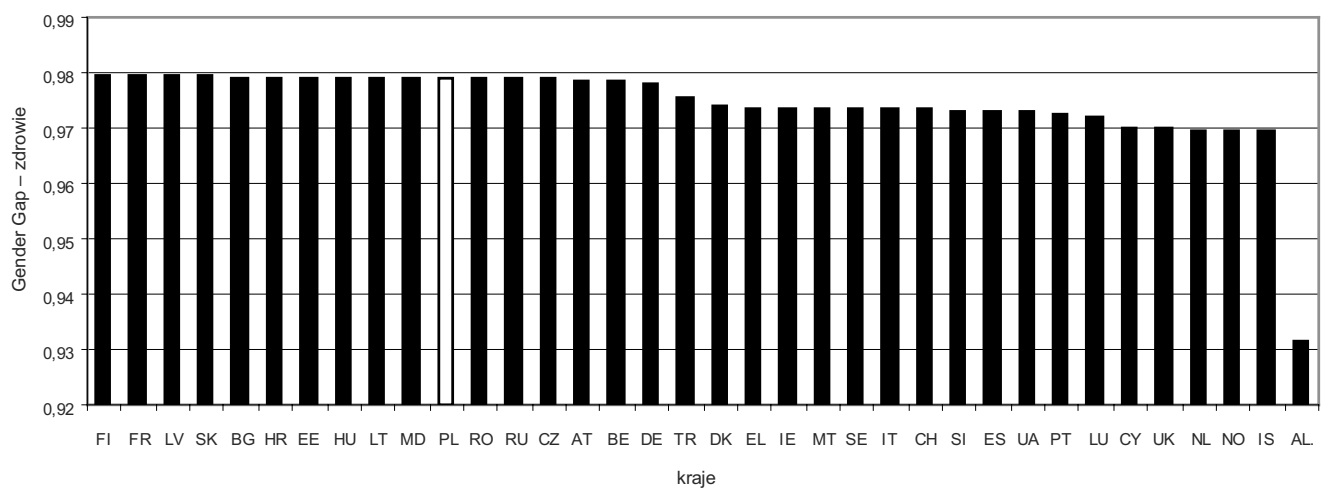

\section{Rysunek 5}

Wskaźnik Gender Gap - zdrowie i długość życia w 2013 roku [\%]; objaśnienia jak pod rysunkiem 1

Źródło: Opracowanie własne na podstawie: The Global Gender Gap Report 2013, World Economic Forum 2013, s. 12-13.

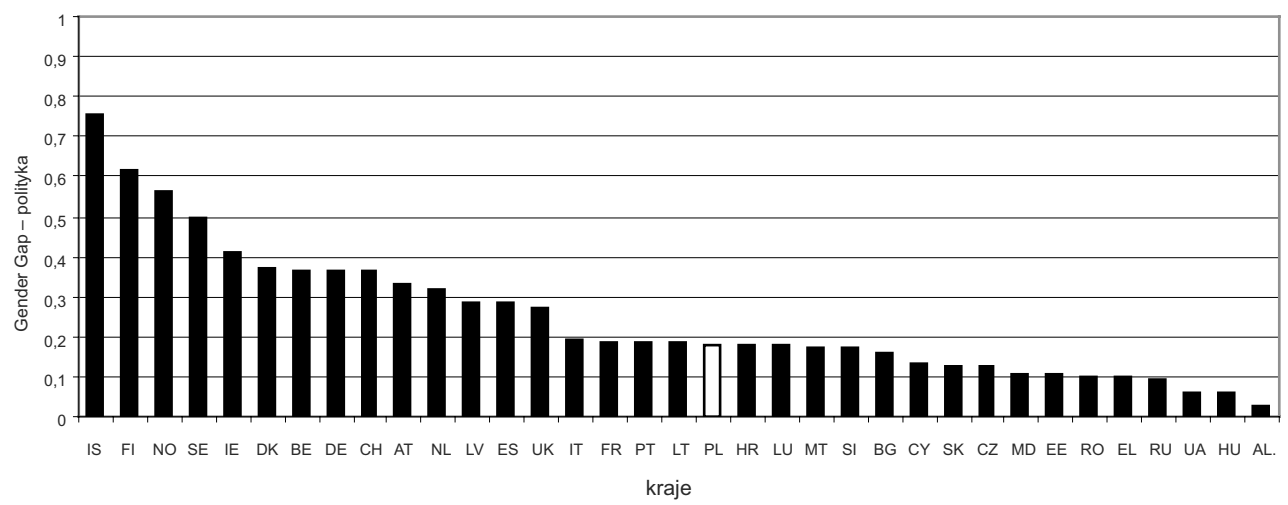

\section{Rysunek 6}

Wskaźnik Gender Gap - równouprawnienie polityczne w 2013 roku [\%]; objaśnienia jak pod rysunkiem 1

Źródło: Opracowanie własne na podstawie: The Global Gender Gap Report 2013, World Economic Forum 2013, s. 12-13.

Wskaźnik oceniający różnice między płciami w obszarze zdrowia, podobnie jak poprzedni subindeks, kształtował się na stosunkowo wysokim poziomie (rys. 5). W 2013 roku w ogólnym rankingu najwyższą pozycję zajęły Finlandia, Francja, Łotwa oraz Słowacja, ze wskaźnikiem 0,9796. Polska znalazła się na 11. miejscu z blisko 98-procentowym wyrównaniem nierówności. Najniższy indeks odnotowano w Albanii - 0,9313. 
Płaszczyzną, w której występują bardzo wyraźne nierówności pomiędzy kobietami i mężczyznami, jest polityka (rys. 6). Jedynie w trzech krajach europejskich subindeks równouprawnienie polityczne kształtował się na poziomie przewyższającym $50 \%$ - w Islandii $75 \%$, Finlandii - $61 \%$ oraz Norwegii - 56\%. Kraje te zajmują trzy czołowe miejsca jeśli chodzi o udział kobiet na stanowiskach ministerialnych: 53\% w Norwegii, 52\% w Szwecji i 50\% w Finlandii. Szwecja zajmuje również drugie miejsce pod względem liczby kobiet w parlamencie ( $45 \%$ ogółu parlamentarzystów to kobiety). W pozostałych państwach indeks był na bardzo niskim poziomie - poniżej 50\%. W Rumunii, Grecji, Rosji, na Ukrainie, na Węgrzech oraz w Albanii osiagnął wartości poniżej 10\%. W tej klasyfikacji Polska znalazła się na 19. miejscu z 17-procentowym poziomem wyrównania nierówności.

\section{Kobiety na obszarach wiejskich}

Przeobrażenia społeczno-ekonomiczne oraz większy napływ ludności z miasta przyczyniły się do zmian w obrębie struktur rodzin wiejskich. Obecnie wiejskie rodziny nie są już tak liczne jak przed laty. Sprawowanie funkcji rodzicielskich również zmieniło swój zasięg jakościowy. To właśnie stosunek do dzieci współczesnej kobiety wiejskiej wymusił nowe zadania.

W krajach europejskich na obszarach wiejskich mieszka wiele kobiet wykształconych, nastawionych na rozwój i samorealizację, świadomych swego potencjału, lecz nieznajdujących na współczesnej wsi odpowiednich warunków społecznych i kulturowych, które pozwoliłyby nie tylko na jego odpowiednie wykorzystanie, ale także na zajmowanie pozycji społecznych odpowiadających temu potencjałowi. Współczesna kobieta wiejska jest ważnym podmiotem wiejskiej społeczności lokalnej, mieszka i identyfikuje się z życiem na wsi, jest połączona więzami ze środowiskiem wiejskim, często łączy elementy tradycji z nowoczesnością.

W Unii Europejskiej rolnictwo to piąty co do wielkości pracodawca mężczyzn, zatrudniający 5\% całkowitej siły roboczej, i siódmy z kolei pracodawca kobiet, dający zatrudnienie 3\% pracujących kobiet. W Europie przeciętnie jedno na pięć gospodarstw prowadzonych jest przez kobietę (rys. 7).

W krajach europejskich w 2012 roku najwyższy odsetek kobiet pracujących w rolnictwie odnotowano w Rumunii - 27\%, w Grecji - 12,5\% oraz w Polsce - blisko $12 \%$, najniższy natomiast w Belgii $-0,9 \%$ oraz w Norwegii i Niemczech - po ok. $1 \%$. W większości krajów europejskich udział kobiet pracujących w rolnictwie kształtuje się na poziomie nieprzekraczającym $5 \%$.

Udział kobiet kierujących gospodarstwem jest zróżnicowany w zależności od kraju i stanowi od ponad 25\% we Włoszech, Austrii, Hiszpanii i Grecji do 


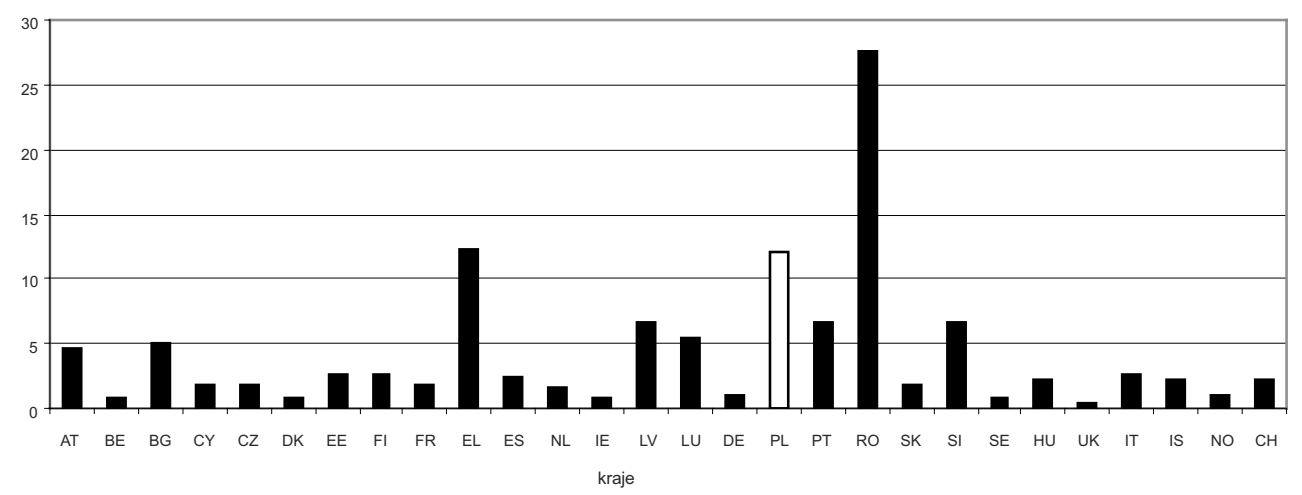

\section{Rysunek 7}

Kobiety pracujące w rolnictwie w krajach europejskich w 2012 roku [\%]; objaśnienia jak pod rysunkiem 1

Źródło: Opracowanie własne na podstawie: http://epp.eurostat.ec.europa.eu (data dostępu: 10.04.2014).

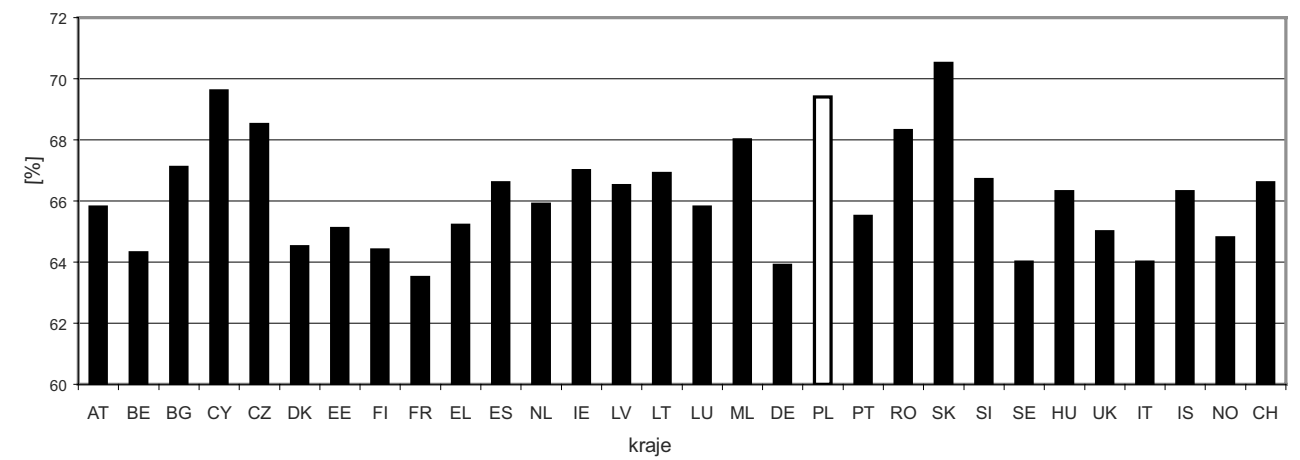

\section{Rysunek 8}

Wskaźnik aktywności zawodowej kobiet na obszarach wiejskich w krajach europejskich w 2012 roku [\%];objaśnienia jak pod rysunkiem 1

Źródło: Opracowanie własne na podstawie: http://epp.eurostat.ec.europa.eu (data dostępu: 10.04.2014).

mniej niż 10\% w Niemczech, Danii i Holandii. Im bardziej rozdrobnione rolnictwo, tym więcej kobiet $\mathrm{w}$ nim pracuje, więcej też gospodarstw kierowanych przez kobiety znajduje się w grupach małoobszarowych gospodarstw.

W krajach Unii Europejskiej aktywność zawodowa kobiet jest wyższa na obszarach zurbanizowanych niż na obszarach wiejskich. Największe różnice pomiędzy aktywnością kobiet z miasta i ze wsi występuje w Bułgarii, na Słowacji i Litwie. Najwyższy wskaźnik aktywności kobiet z obszarów wiejskich wystę- 
puje na Słowacji (70,5\%), Cyprze (69,6\%) oraz w Polsce (69,4\%), a najniższym charakteryzuje się Francja $(63,5 \%)$ - rysunek 8 .

Wiele kobiet, które są partnerkami w rodzinnych przedsiębiorstwach rolnych, a nie pracownicami, może znaleźć się poza zasięgiem ustawodawstwa w zakresie bezpieczeństwa i higieny pracy. Niektóre państwa członkowskie, takie jak Wielka Brytania, podjęły decyzję o traktowaniu takich pracowników rolnych jako pracowników, wobec których stosowane będzie ustawodawstwo w zakresie bhp, a także uwzględniły tę kwestię w wytycznych dla sektora. Kobiety pracujące w rolnictwie mogą być narażone na takie same zagrożenia i ryzyko, co mężczyźni, jednak dodatkowo są narażone na inne ryzyko, głównie dotyczące płodności (np. spowodowane pestycydami i czynnikami biologicznymi). Oprócz tego kobiety mogą być silniej narażone na związane z pracą urazy szyi i kończyn górnych.

\section{Wnioski}

Rozważania dotyczące nierówności między kobietami i mężczyznami w krajach europejskich, podjęte w tym opracowaniu, skłaniają do sformułowania następujących wniosków:

1. Definicje nierówności społecznych związane są ściśle z sytuacją społeczną, ulegają tak jak i ona zmianom. Występują pewne rodzaje nierówności, tzw. tradycyjne, których opisywanie od wielu lat odbywa się w tych samych kategoriach, a zmianie ulega jedynie ich empiryczny wymiar.

2. Uwzględniając dane statystyczne Eurostatu można potwierdzić, iż w krajach europejskich występuje dyskryminacja płacowa kobiet. Różnice w wysokości wynagrodzeń są rezultatem nakładania się wielu czynników o charakterze prawnym, społecznym i kulturowym.

3. W 2013 roku w Islandii, Finlandii, Norwegii i Szwecji wskaźnik Global Gender Gap kształtował się na poziomie przewyższającym $80 \%$ - tzn. udało się tym krajom zlikwidować większość nierówności ze względu na płeć w różnych sferach życia. Na dole rankingu znalazły się kraje, które nadal potrzebują niwelowania dysproporcji w pozycji kobiet i mężczyzn - Albania, Wegry oraz Malta.

4. W 2013 roku państwa europejskie najbardziej zbliżyły się do standardu równości w obszarze edukacji, a następnie zdrowia. Zdecydowanie największa nierówność oraz zróżnicowanie wystąiło w obszarze władzy politycznej.

5. W krajach, w których mechanizacja rolnictwa jest na wysokim poziomie, zmniejsza się zapotrzebowanie na kobiecą siłę roboczą, z drugiej jednak strony panuje przeświadczenie, że praca kobiet w gospodarstwie jest bar- 
dziej wszechstronna i elastyczna. W Europie przeciętnie jedno na pięć gospodarstw prowadzonych jest przez kobietę.

\title{
Literatura
}

GOODMAN N., 1988: Wstęp do socjologii, PWN, Warszawa, s. 125.

KOKOCIŃSKI M., 2009: Metodologiczne aspekty badania nierówności społecznych, [w:] Spór o społeczne znaczenie społecznych nierówności, red. K. Muzia, Wydawnictwo Naukowe Uniwersytetu im. Adama Mickiewicza w Poznaniu, s. 14.

RAWŁUSZKO M., 2007: Gender Index a inne wskaźniki równościowe, [w:] Monitorowanie równości kobiet i mężczyzn w miejscu pracy, red. E. Lisowska, GenderIndex, Warszawa, s. $17-18$.

SOBCZAK E., 2013: Gender analysis jako narzędzie statystycznej oceny realizacji zasady równych szans kobiet i mężczyzn w państwach Unii Europejskiej, Prace Naukowe Wałbrzyskiej Wyższej Szkoły Zarządzania i Przedsiębiorczości w Wałbrzychu, t. 23, Wyd. WSZiP, Wałbrzych, s. 72.

SZTOMPKA P., 2002: Socjologia, Znak, Kraków, s. 332.

Gender pay gap statistics, Eurostat, http://epp.eurostat.ec.europa.eu/statistics_explained/index.php/Gender_pay_gap_statistics (data dostępu: 10.04.2014).

Przeciwdziałanie różnicy w wynagrodzeniu dla kobiet i mężczyzn w Unii Europejskiej, Urząd Publikacji Unii Europejskie, Luksemburg 2014, s. 5.

The Global Gender Gap Report 2013, World Economic Forum, 2013.

TURNER J., MUSICK D. 1985: American Dilemmas. A Sociological Interpretation of Enduring Social Issues, Columbia University Press, New York, s.217.

ZACHOROWSKA-MAZURKIEWICZ A., 2011: Istota nierówności w procesie rozwoju - podejście instytucjonalne, [w:] Wspótczesne wymiary nierówności w procesie globalizacji, (red.) E. Okoń-Horodyńska, A. Zachorowska-Mazurkiewicz, Wydawnictwo Uniwersytetu Jagiellońskiego, Kraków, s. 12.

http://epp.eurostat.ec.europa.eu (data dostępu: 10.04.2014).

\section{Gender Gap - gender based inequalities in European countries}

\begin{abstract}
This study elaborates on the problem of gender-based inequality in European countries. The first part discusses main trends in defining inequalities and discrimination. The second part includes an analysis of inequality based on the wage gap index and the Global Gender Index. Obtained results confirmed the existence of social inequality based on gender in European countries. Due to differences in its levels among different European countries in 2012-2013 it was
\end{abstract}


possible to isolate two groups of countries. The first group includes Iceland, Finland, Norway and Sweden, that have been able to eliminate most of gender-based inequalities in various spheres of life. The second group consists of countries that need to reduce the disparities between positions of women and men - these include Albania, Hungary and Malta. 